\title{
Does Comprehensive Education Work for the Long-term Unemployed?
}

\author{
Anders Stenberg ${ }^{*}$ and Olle Westerlund ${ }^{* *}$
}

\begin{abstract}
This paper evaluates the effects of comprehensive adult education on wage earnings of the long-term unemployed, an essentially unexplored issue. We use register data pertaining to a large sample of long-term unemployed persons in Sweden who either enrolled in the comprehensive adult education program, participated in labour market training, or remained in open unemployment. We find that individuals with more than one semester at upper secondary level of the comprehensive adult education program experienced an increase in annual wage earnings compared with those who remained in open unemployment. For those studying at the compulsory level we find no significant effects. The estimated effects were overall negative in relation to vocational labour market training.
\end{abstract}

Keywords: Adult education, long-term unemployed, wage earnings

JEL classification: J68, H52

* SOFI, Stockholm University, SE-106 91 Stockholm. E-mail: anders.stenberg@sofi.su.se

** Department of Economics, Umeå University, SE-901 87 Umeå. E-mail: olle.westerlund@econ.umu.se 


\section{Introduction}

Adult education has become an increasingly important policy tool in most OECD countries. Changing skill requirements, rising unemployment and the potential growth effects of human capital investment are major factors behind this development. Despite the explicitly declared economic goals of policy makers, and despite the substantial resources devoted to adult education (or 'lifelong learning') over many years, very little is known about its economic effects. In this study, we use a sample of long-term unemployed to evaluate the effects on gross wage earnings of comprehensive adult education as compared with vocational training or continued open unemployment.

There is a substantial literature dealing with the effects of education on income; but the proportion devoted to the education of adults is a tiny fraction and only a few of these focus on the unemployed. To our knowledge, there is no previous study measuring the effects on income of comprehensive education of the long-term unemployed. This is somewhat surprising, since studies in this field should be highly relevant to policy makers. Rising unemployment has in most countries been accompanied by an increased share of the long-term unemployed as well as increasing amounts being spent within the framework of regular labour market policy. Presumably, one would expect decreasing marginal returns on additional spending and therefore, a growing interest in alternative measures. Formal comprehensive education targeted to the unemployed is a straightforward measure that can easily be implemented in many countries. If successful, it may serve the triple purpose of reducing social welfare costs, increasing production in the economy and reducing income inequalities.

Our empirical analysis is based on Swedish data from a period of massive expansion of heavily subsidized adult education. In 1997, the Swedish government launched the Adult Education Initiative (AEI), a program in effect up to 2002 that offered primarily the unemployed a 
year of full time comprehensive education at compulsory or upper secondary level, with financial support corresponding to their respective unemployment insurance (UI) benefits. The AEI emerged largely as a response to high unemployment rates during the economic recession of the 1990's. Between 1990 and 1993, real GDP per capita decreased by $6.4 \%$ and the fraction of those openly unemployed rose from 1.7 to 8.2 $\%$ of the total labour force (see Figure 1). In the Swedish context, this was the highest recorded unemployment rate since the depression of the 1930's. In 1997, open unemployment still remained high despite historically high numbers of participants in active labour market programs during the first half of the 1990's. This gave rise to increasing concern regarding the marginal returns on traditional labour market measures.

Fig 1; Unemployment, labour market programs and adult education in Sweden 1990 - 2003 (in percent of total labour force).

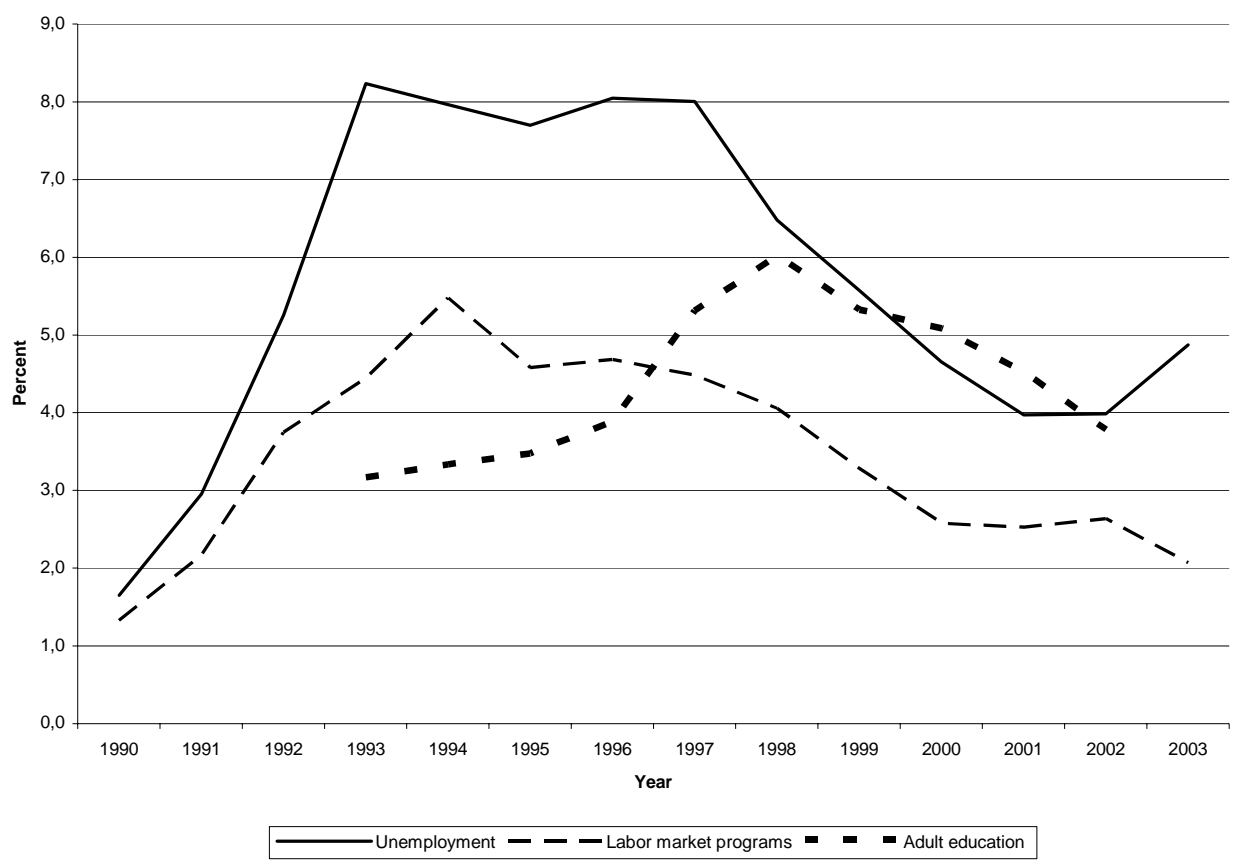

Note: 'Adult education' denotes the number of individuals enrolled in at least one course. This includes a large fraction attending only short courses. Unemployment and labour market programs are measured as yearly averages. 
As in many other European countries, there was a high rate of unemployment among those with a relatively low level of education and also a growing number of the long-term unemployed. In Sweden, the relative labour market position of these groups had also been influenced by school reforms at the beginning of the 1990's, whereby the two-year upper secondary programs were extended to three years to conform with university entrance requirements.

The circumstances provided persuasive arguments in favour of additional public expenditure on adult education. A year of studies within the AEI not only offered an alternative to traditional labour market programs, but was also a way of bridging the educational gap of the groups with only two-year upper secondary school from the previous system of education. Official documents described the subsidized education as a means to achieving a host of targets, including income redistribution, encouragement of further studies, enhancement of economic growth and the reduction of unemployment.

Between the autumn semester of 1997 and the spring semester of 1999 , persons in the AEI represented $1.2-1.5 \%$ of the total labour force. The numbers exceeded those in Labour Market Training (LMT), which until 1997 was the largest labour market program in Sweden. The AEI was targeted towards very much the same groups as LMT. In both programs, the training grant equalled the UI. The policy declarations of both programs made it a priority to support individuals with a weak position in the labour market. Completing a course in either program lasting more than six months also qualified for a new period of 300 days with unemployment benefits.

LMT consisted of two groups, those in vocational training and those in preparatory training. The vocational courses were directed towards the acquisition of skills that were expected to be in short supply on the labour market. The preparatory training was intended to prepare the indi- 
vidual for further training, i.e. the immediate aim not being to achieve a rapid transition to work. ${ }^{1}$

Economic evaluations of comprehensive adult education represent a surprisingly small literature. ${ }^{2}$ A UK study by Jenkins et al. (2003) finds, with minor exceptions, no evidence of positive effects of mid-career education on wages or employment. Other studies based on UK data focus on higher education and "mature graduates" who for the most part are still under 30 when completing their studies. A general finding is that mature graduates receive smaller wage gains from a degree in comparison with younger graduates (e.g. Egerton \& Parry, 2001, Steel \& Sausman, 1997). Studies from the US include Leigh and Gill (1997) who analyze the effects of community college on log wages for "adults", aged mainly 25 to 35 . They find positive effects on earnings and that the returns do not decline for older students (see Grubb (2002) for an extensive survey of evaluations in the US). Employing Swedish data, Ekström (2003) analyzes adult education at upper secondary level and reports effects on income that are negative for men born in Sweden but positive for immigrants. Concerning higher education, Öckert (2001) finds older persons to have more difficulties with completing their studies but better returns once they do so.

The few economic studies that examine comprehensive adult education of the unemployed also show mixed results. Jacobson et al. (2004) use a sample of laid-off workers in Washington State to study the effects of attending a community college. The workers were of prime age and took a broad variety of courses, ranging from basic skills to vocational training to academic courses in mathematics and science. In summary, they report increases in earnings in the neighbourhood of $10 \%$, slightly

\footnotetext{
${ }^{1}$ Evaluations of the impact of LMT based on participant data in 1989 or later generally report insignificant or detrimental effects, see e.g. Harkman et al. (1996), Harkman (1997), Regnér (1997), Larsson (2000), Sianesi (2001), and Richardson \& van den Bergh (2002). It is possible that these results are influenced by the economic recession discussed above. Okeke (2001), using data of LMT participants 1998-99, finds positive effects on the probability of being employed six months after program completion.

${ }^{2}$ There are a large number of studies dealing with on-the-job training. However, in most cases they address shorter training periods and largely vocational or industry-specific training.
} 
lower for males and slightly higher for females. The returns are up to three times larger for technically oriented courses. Stenberg (2003) uses a sample of unemployed persons in Sweden and finds the effects on annual wage earnings weaker for those in comprehensive adult education than for participants in vocational LMT. ${ }^{3}$

In this study, we concentrate on the effects of the AEI on wage earnings of the long-term unemployed, comparing the AEI with the alternative of "no program" as well as with participating in LMT. Sweden is an appropriate locus for this investigation since the broad scope of labour market policies and the excellent data allow us to study a very large sample of the long-term unemployed. We are not aware of any previous such studies involving adult comprehensive education.

Participants in labour market programs often have lower incomes in the year before enrolment. As this study focuses on the long-term unemployed it involves participants and non-participants with reasonably similar wage trajectories prior to program. We have access to annual wage earnings four years prior to program participation. This enables us to consider systematic group-wise income differentials that remain unexplained by either observable individual attributes or regional affiliation. Of course, conditioning on unemployment and/or previous wage earnings histories is not necessarily sufficient to eliminate the problem of selection bias. Our approach here is to use a form of "backcasting" introduced by Ashenfelter (1978), which is a simple but efficient tool to check for the presence of selection bias due to time-invariant differences in ability and/or motivation.

From a theoretical standpoint, there are no obvious reasons to expect differences in wage earnings gain from comprehensive education vis-àvis vocational training. The hypothetical effect on annual wage earnings is due to their impact on the probability of employment and on the wage level, which may both stem from either pure screening effects or

\footnotetext{
${ }^{3}$ The economic efficiency of the AEI has been questioned. Both Björklund et al. (2003) and Ekström (2003) expressed doubts about the efficiency of offering adult education at virtually no opportunity costs for the unemployed.
} 
actually increased productivity. Regarding the effect on productivity, both programs may lead to increased skills and improvement of the job matching process by providing productive skills in demand. Moreover, there are no or dispensable private costs for education in this case. Differences in private costs would otherwise imply differences in posteducation earnings. Therefore, the relative economic outcomes of these two educations are strictly empirical issues.

The potential effect of education on income as compared with the alternative of remaining in open unemployment should be positive or at least non-negative. However, the signalling or productivity effects of education on income may, at least partially, be matched by a positive effect of a higher intensity of job searching among the openly unemployed. This could lead to a higher probability of employment and longer tenure at the time of ex-post observation. Taken together, the answer lies with the data.

The plan of the paper in the following is to describe the data (Section 2), to present the estimation results (Section 3) and to present a brief concluding discussion (Section 4).

\section{Data}

This study is based on data from various official registers administered by Statistics Sweden and records from the Swedish National Labour Market Administration (AMS). These data originate from the total population register, the income register, the register of adult education and the event history database Händel kept by AMS. Händel covers virtually all unemployed persons in search of work, since registration at the local public employment office is mandatory in order to receive unemployment benefits. Registered job seekers are followed on a day-today basis and are classified in different categories depending on whether they are openly unemployed or participants in some labour market program, e.g. LMT. Participation in the AEI, however, is not 
registered in Händel. This information is collected instead from the adult education register.

The data at our disposal consists of 538,004 individuals divided into three groups

1. the stock of those openly unemployed who were registered in Händel on September 1, 1997, N = 283,560.

2. the stock of participants in LMT who were registered in Händel on October 15, 1997, $\mathrm{N}=32,235$.

3 . the individuals registered in adult education at some time during the autumn semester of $1997, \mathrm{~N}=222,209$.

Those in adult education were enrolled at the municipal adult education institute komvux. ${ }^{4}$ Participants in the AEI in the autumn of 1997 can be singled out since they were eligible to apply for the special grant for education and training (the UBS). This was a subsidy equal in size to UI benefits that was granted for the purpose of stimulating adult education. Individuals had to be $25-55$ years old, enrolled for studies at compulsory or upper secondary level and be entitled to UI when the studies were initiated. Those who were registered in adult education and received UBS are defined as participants in the AEI and consist of 55,965 observations of which more than $80 \%$ were enrolled at upper secondary level and studied the compulsory subjects mathematics, Swedish, social science and English (Government Commission Report, SOU 1998:51). There were other theoretical subjects besides these but about a fourth of the participants also attended at least one vocational course. $^{5}$

In our data we can distinguish between AEI participants at upper secondary and compulsory level, excepting a group of about $15 \%$ where reported level of studies was missing. Apart from this, we have no individual records of the specific courses attended.

\footnotetext{
${ }^{4}$ All municipalities have offered adult education at komvux since the early 1970's. For the AEI the government supplied extra funds to meet the increased demand.

${ }^{5}$ Small fractions of participants in the AEI and LMT may have attended the same vocational courses as $5 \%$ of the vocational courses at LMT were purchased from komvux.
} 
Individuals in LMT participate either in vocational training (68\%) or preparatory training. The vocational part is closely connected to labour market needs and the training sometimes, wholly or partially, takes place on site within a workplace. Preparatory training includes courses in job-seeking and/or preparations for other programs.

To be defined as long-term unemployed, we required the individuals to have been registered in Händel for 366 days in 1996 and for 365 days in 1997. As those enrolled in the AEI were deactivated from the unemployment registers, the condition for them in 1997 is " 220 days or more". An alternative was to set this condition for all groups, but doing so affected the results presented in Section three only marginally. Some of the unemployed were working part time, but at this stage we excluded no one on the basis of income.

Individuals were excluded if they participated in adult education at komvux in 1996 or in the spring semester of 1997 or in other types of education in the years following 1997. Those in the AEI or in open unemployment were excluded if they had enrolled in LMT during the period 1998 - 2000, while the participants in LMT and those in open unemployment were excluded if they had enrolled in the AEI in any year. Finally, we also excluded individuals younger than 25 and older than 55 years of age.

The sample now consists of 51,051 individuals. Participants in the AEI include 5,189 at upper secondary level and 585 at compulsory level. The vocational part of LMT includes 5,033 individuals and LMT preparatory training 2,065 individuals.

Program lengths vary greatly within the sample, ranging from a couple of weeks to slightly over two years. Generally, longer programs apply for the participants in the AEI as compared with participants in LMT. The distribution of program lengths is provided in Table A.1 in the Appendix. Individuals who dropped out prematurely from training cannot 
be identified. This means that 'participation' should be interpreted as started program rather than completed program. ${ }^{6}$

Table 1 presents sample means of selected individual characteristics. The number of days in unemployment in 1995 was very similar across groups, but wage earnings in pre-program years are higher in the group of AEI participants. The wage earnings measure includes gross salary, holiday compensation and taxable benefits but not transfers such as UI. Judging from these figures, part-time employment seems to have been more frequent within this group.

Table 1. Sample means of various characteristics among the openly unemployed and participants in the AEI and LMT.

\begin{tabular}{lrrr}
\hline & $\begin{array}{c}\text { Openly } \\
\text { unemployed }\end{array}$ & LMT & AEI \\
\cline { 2 - 4 } & & & \\
Number of observations & 38,178 & 7,098 & 5,774 \\
Days in unemployment in 1995 & 311 & 307 & 310 \\
Wage earnings 1995 (SEK) & 38,587 & 37,523 & 46,954 \\
Wage earnings 1996 (SEK) & 26,774 & 26,574 & 41,143 \\
Age & 42.6 & 39.5 & 38.1 \\
2-year upper secondary school & .410 & .422 & .614 \\
Male & .447 & .432 & .705 \\
Married & .387 & .395 & .366 \\
Child(ren) & .314 & .385 & .487 \\
Non-Scandinavian & .074 & .148 & .036 \\
Eligible for UI & .891 & .854 & .969 \\
Disabled & .276 & .197 & .152 \\
Stockholm County & .112 & .123 & .099 \\
Inland of Norrland & .070 & .058 & .073 \\
High municipal \% of upper sec. & & & \\
school & .501 & .534 & .386 \\
\hline
\end{tabular}

${ }^{6}$ According to AMS (1999), the dropout rate from the vocational training part of LMT was $18 \%$ in the second quarter of 1998 . With regard to the AEI, the Government Commission Report (SOU 1999:39) stated that $10 \%$ interrupted their studies. These figures include individuals who interrupted their program because they found work. 
The largest differences in Table 1 are between the participants in the AEI and the rest of the sample. The AEI attracted foremost women and there are fewer with relatively high or low educational levels. Note that individuals were eligible to apply for the special grant (UBS) even with a formally completed upper secondary level. The condition was in case they did not have passes in all subjects or "the required knowledge" in one or more subjects. Further, persons who were long-term unemployed or had an 'old' secondary education could also apply. ${ }^{7}$ A more detailed account, including variable definitions, is given in the Appendix.

The trajectories of the annual wage earnings for the different subgroups are displayed in Figure 1. In 1993, the averages between the AEI upper secondary level, vocational LMT and the group with no program differed by only SEK 100 , i.e. $€ 11$ - $€ 12$ during the period of study; and up until 1997 the trajectories remained fairly similar, except for the AEI secondary which was slightly higher. After 1997, however, there were substantial increases in gross wage earnings. The most important occurred for participants in the vocational part of LMT followed by those at upper secondary level within the AEI. Participants at compulsory level in the AEI had average wage earnings in 2001 that were below the level of those who had continued in open unemployment.

Figure 2 also shows the wage earning trajectories but conditions them to be zero in 1996 and 1997. The relative levels now change slightly. Foremost, the LMT preparatory training trajectory is above that of the AEI upper secondary level. There is no indication of a relatively stronger pre-education income shock for any of these groups.

\footnotetext{
${ }^{7}$ In the groups with the highest and lowest educational levels, foreign citizens and older age groups were overrepresented. An exception to this rule is the no longer existing elementary level which concerns very few foreign citizens, having been replaced stepwise between 1962 and 1972 by the present nine-year compulsory school.
} 
Fig 2. Labour income trajectories of different subgroups.

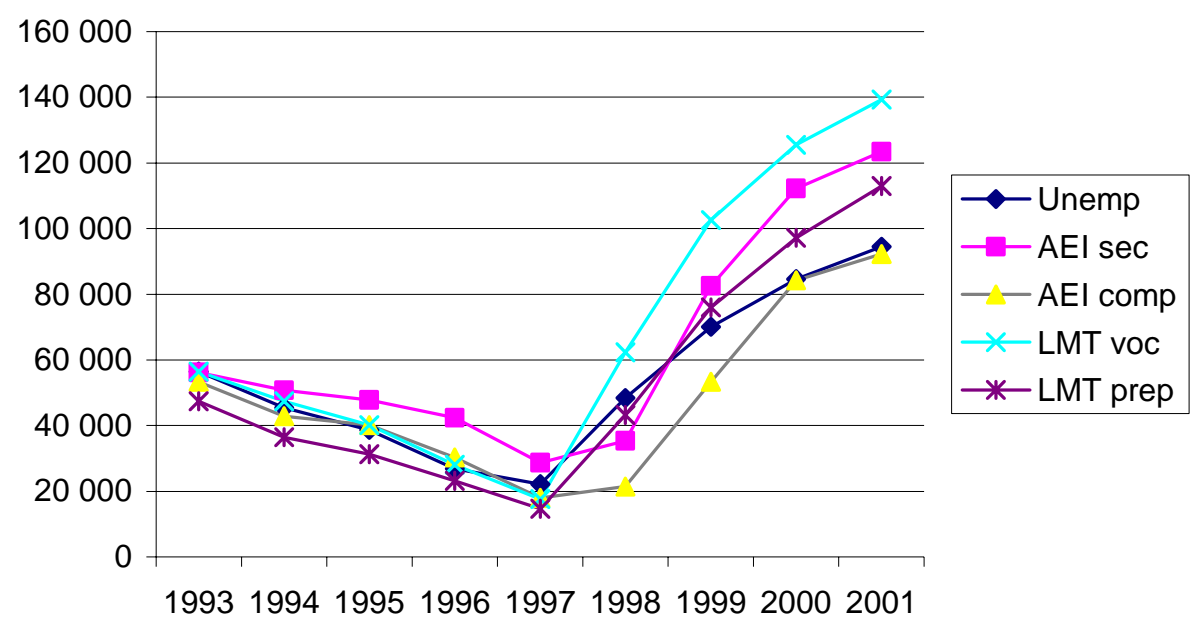

Fig 3. Labour income trajectories conditioned so that wage earnings are zero in 1996 and in 1997.

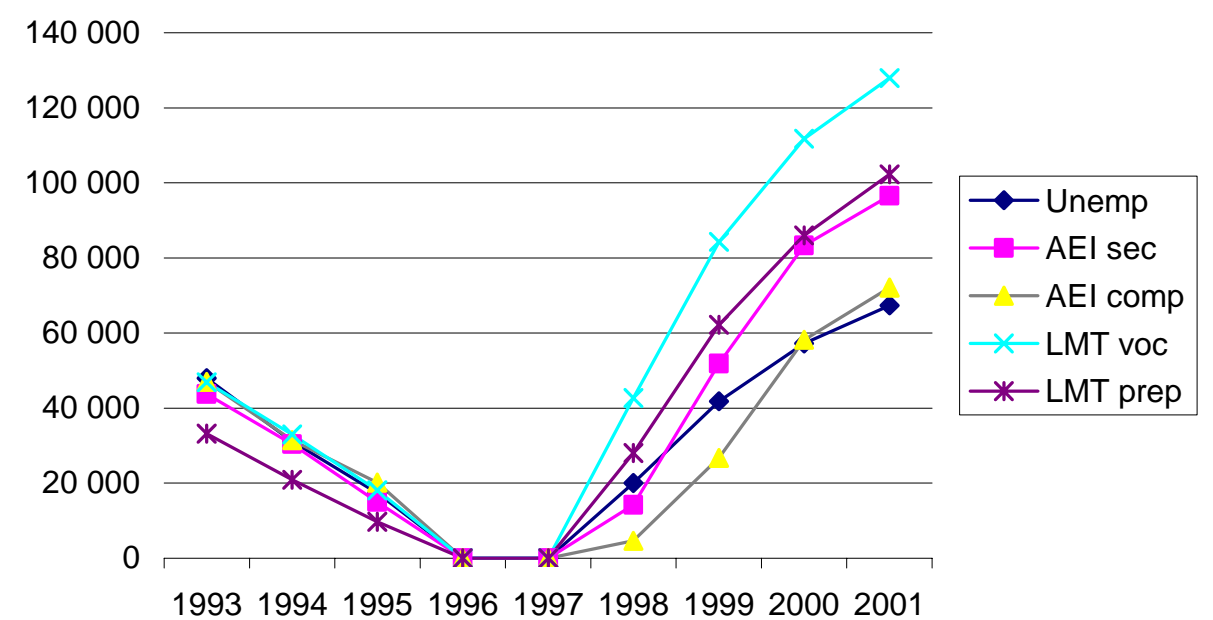




\section{Estimations}

In this section, we present ordinary least squares (OLS) estimates of regressions on annual wage earnings for the long-term unemployed, including a version where the sample restriction is zero wage earnings in 1996 and in 1997. Before we turn to the backcasting procedure, there is a brief discussion on alternative estimation techniques that explicitly take selection into account. The results are then summarized and also set in relation to the officially reported program costs.

The main methodological concern in evaluation studies based on nonexperimental data is the potential ability bias which may flaw OLS estimates. As was apparent in Table 1, there were differences in the observable characteristics, foremost between those in the AEI and the rest of the sample. One may then suspect that there might also be differences in unobservable characteristics, such as motivation and/or some kind of individual ability. This occurs if individuals are aware of and act upon their expected returns on a program. This then attracts a positive selection, one with a higher than average expected return. An opposing mechanism is that individuals with a high probability of finding work will face higher expected costs in terms of forgone earnings and therefore have a lower probability of enrolling in a program. In the presence of such mechanisms, OLS estimates are inconsistent due to omitted variables in the econometric model. On the other hand, given that the pre-program wage trajectories were relatively similar, one would à priori expect the problem of selection bias to be limited.

Let us nevertheless first use OLS estimates as a point of departure before we address the issue of possible selection bias. Assuming that the program occurs at time $t$, the OLS regression specification we use can be written

$w_{i, t+}=\alpha+X_{i, t}^{\prime} \beta+\theta w_{i, t-}+\gamma d_{i, t}+e_{i}$ 
where $w_{i, t_{+}}$is post-program wage earnings and $w_{i, t-}$ pre-program wage earnings, $\alpha$ is a vector of constants, $X_{i, t}$ contains individual and regional variables and $d_{i, t}$ is a vector of program participation dummies. In this setting, to make $\gamma$ a consistent estimate of the program specific effects, the crucial assumption is that $w_{i, t-}$ can take account of unobservables such as individual ability and/or motivation. Our explanatory variables include wage earnings in 1996, their deviation from the mean squared and a dummy indicating zero wage earnings before program. As an alternative, we ran a regression on $w_{i, t-}$ and used the residuals instead of the actual wage earnings as $w_{i, t .}$ Moreover, given the fractions of zero wage earners, we also employed a Tobit model. However, these approaches yield results that are qualitatively similar to those presented in this section. The estimated parameters of main interest are shown in Table 2 below while the complete results are presented in Table A.3 in the Appendix.

Table 2. OLS estimation results of program effects on wage earnings.

Dependent variable; annual wage earnings 2001.

\begin{tabular}{|c|c|c|c|c|}
\hline \multirow{3}{*}{ Reference group: } & \multicolumn{2}{|c|}{ Openly unemployed } & \multicolumn{2}{|c|}{ LMT vocational } \\
\hline & Men & Women & Men & Women \\
\hline & $\mathrm{N}=26,800$ & $\mathrm{~N}=24,251$ & $\mathrm{~N}=5,729$ & $\mathrm{~N}=7,143$ \\
\hline \multicolumn{5}{|l|}{ AEI compulsory } \\
\hline 1 semester & $-8,355$ & $-16,425$ & $-41,747^{* *}$ & $-43,969^{* * *}$ \\
\hline 2 semesters & $-9,132$ & $-8,958$ & $-44,129^{* * *}$ & $-35,234^{* * *}$ \\
\hline 3 semesters & $-20,672$ & $-6,556$ & $-56,354^{* * *}$ & $-33,942^{* * *}$ \\
\hline 4 semesters & 3,634 & $-3,098$ & $-29,704^{* *}$ & $-31,149^{* * *}$ \\
\hline \multicolumn{5}{|l|}{ AEI upper secondar } \\
\hline 1 semester & $13,349^{* *}$ & 4,020 & $-21,967^{* * *}$ & $-22,146^{* * *}$ \\
\hline 2 semesters & $29,508^{* * *}$ & $15,492^{* * *}$ & $-4,706$ & $-9,771^{* * *}$ \\
\hline 3 semesters & $21,142^{* * *}$ & $21,757^{* * *}$ & $-14,166^{* *}$ & $-3,214$ \\
\hline 4 semesters & $11,515^{* *}$ & $12,306^{* * *}$ & $-22,853^{* * *}$ & $-13,066^{* * *}$ \\
\hline \multirow{3}{*}{$\begin{array}{l}\text { LMT vocational } \\
\text { LMT preparatory }\end{array}$} & $35,674^{* * *}$ & $25,480^{* * *}$ & -- & -- \\
\hline & $20,069^{* * *}$ & $11,185^{* * *}$ & $-17,605^{* * *}$ & $-16,301^{* * *}$ \\
\hline & .131 & .158 & .108 & .121 \\
\hline
\end{tabular}

Note: $\quad{ }_{* * *}^{*}$ significant at the $1 \%$ level.

** significant at the $5 \%$ level.

significant at the $10 \%$ level. 
In the first two columns, the openly unemployed constitute the group of reference. The results then indicate the effects of the AEI or LMT compared with no measure taken. The last two columns show results from using those in LMT vocational training as the comparison group (the openly unemployed are in this case excluded).

The results of the first two columns indicate that the AEI at compulsory level had no significant effects compared with no training. The estimated parameters on the AEI at upper secondary level indicate positive effects. For those with only one semester of studies the coefficient is positive for men but insignificant for women. LMT preparatory and LMT vocational training also seem to have had positive effects. In the last two columns, the indication is that the effects on wage earnings of the AEI and LMT preparatory training were inferior to those achieved by LMT vocational training.

When we restrict the sample to include only those with zero wage earnings in 1996 and in 1997, we also exclude those at compulsory level in the AEI as the number of individuals becomes very small (generally below 30 observations). The fractions retained in the other groups vary from $26 \%$ (AEI upper secondary) to $44 \%$ (LMT preparatory). Results from OLS regressions are presented in Table 3 below.

The estimates in Table 3 generally repeat the findings that, compared with no program, both the upper secondary level of the AEI exceeding one semester of studies and LMT were measures that enhanced annual wage earnings. The coefficient values of the AEI are higher as compared with the corresponding coefficients in Table 2, apart from those who left after only one semester. Also reproduced are the relatively negative coefficients of the AEI vis-à-vis LMT. This latter result was also found in Stenberg (2003), with samples of both men and women who had zero wage earnings in the year prior to program. Throughout, finally, LMT preparatory training appears to have had positive effects on wage earnings but also, as expected, that these effects were inferior to those achieved by LMT vocational training. 
Table 3. OLS estimation results of program effects on wage earnings, sample with zero wage earnings in $1996-1997$.

Dependent variable; annual wage earnings 2001.

\begin{tabular}{|c|c|c|c|c|}
\hline \multirow[t]{3}{*}{ Reference group: } & \multicolumn{2}{|c|}{ Openly unemployed } & \multicolumn{2}{|c|}{ LMT vocational } \\
\hline & Men & Women & Men & Women \\
\hline & $\mathrm{N}=10,944$ & $\mathrm{~N}=6,799$ & $\mathrm{~N}=2,331$ & $\mathrm{~N}=1,668$ \\
\hline \multicolumn{5}{|c|}{ AEI upper secondary } \\
\hline 1 semester & $-1,164$ & -574 & $-50,627^{* * *}$ & $-34,730^{* * *}$ \\
\hline 2 semesters & $42,072^{* * *}$ & $22,980^{* * *}$ & $-6,024$ & $-11,879^{*}$ \\
\hline 3 semesters & $25,829^{* * *}$ & $33,609^{* * *}$ & $-22,720^{* *}$ & -220 \\
\hline 4 semesters & $20,889^{* *}$ & $17,165^{* * *}$ & $-26,488^{* * *}$ & $-19,037^{* * *}$ \\
\hline \multirow{3}{*}{$\begin{array}{l}\text { LMT vocational } \\
\text { LMT preparatory }\end{array}$} & $49,776^{* * *}$ & $35,842^{* * *}$ & -- & -- \\
\hline & $27,070^{* * *}$ & $24,603^{* * *}$ & $-22,768^{* * *}$ & - 7,294 \\
\hline & .120 & .123 & .121 & .105 \\
\hline
\end{tabular}

Note: $\quad{ }^{* * *}$ significant at the $1 \%$ level.

** significant at the $5 \%$ level.

significant at the $10 \%$ level.

Now, since the OLS regression results may be flawed by selection bias, an alternative method is to use a version of the Heckman two-step method, which given certain assumptions also considers differences in unobservable characteristics between the program participants (see e.g. Greene, 2003). However, this method is difficult to use, as to be properly identified it normally requires an instrumental variable (IV). If the model is only weakly identified, the standard errors become inflated and the coefficient values unreliable (see e.g. Puhani, 2000 and Vella, 1998). A valid IV should be able to explain enrolment but have no explanatory power in the outcome regression. As is well known, a variable with such properties is hard to find.

We re-estimate the coefficients in Table 2 with the two-step method using participation in the AEI as our dependent variable in the first step probit regression. The model yields coefficient values that indicate serious identification problems (for completeness, the results are presented in Table A.4 in the Appendix). In an attempt to resolve the problems of identification, different candidate variables were used as in- 
struments. We also experimented with excluding LMT and compulsory AEI from the larger sample to possibly simplify the modelling of the first step. However, the problems of identification remained and/or the (combination of) IVs turned out to be invalid. ${ }^{8}$

A different approach to the problems connected with unobservable variables is sometimes labelled "backcasting". Introduced by Ashenfelter (1978), the basic idea is to run the OLS regression on annual wage earnings before program, that is, estimate whether there are effects of a program before it occurs (see e.g. Heckman et al. 1999 and Jacobson et al. 2004). If the econometric model is correctly specified, the parameters of program participation should be zero. In contrast, if they are significantly different from zero, this serves to indicate the presence of selection bias. Presumably, if no bias is indicated with the backcasting procedure and given that we have taken into account individuals' preprogram labour market performance, we should substantially have reduced the potential bias due to time-invariant unobserved heterogeneity affecting wage earnings. Of course, there may still be potential problems with selectivity bias when program participation is determined by comparative advantages depending on unobservable traits of the individuals.

In Table 4, we present regression results using wage earnings in 1996 as dependent variable (upper part), and wage earnings in 1995 for the sample that was conditioned to have zero wage earnings in 1996 (lower part). The explanatory variables are the same as before except that wage earnings in 1993 is used as $w_{i, t .}$. The samples correspond to those in Table 2 and Table $3 .{ }^{9}$

\footnotetext{
${ }^{8}$ Candidate IVs include the municipal fractions assigned in the AEI compared with LMT and the municipal fractions of 25-64 year olds enrolled in komvux. Validity was checked by way of a simple likelihood ratio test. The hypothesis that the instrumental variable(s) had no explanatory power in the outcome regression was rejected.

${ }^{9}$ Due to missing observations of the wage earnings variable in 1993, these samples are slightly reduced.
} 
Table 4. "Backcasting" regressions on annual wage earnings before program.

Full sample:

Dependent variable; annual wage earnings 1996.

Reference group:

\begin{tabular}{|c|c|c|c|}
\hline \multicolumn{2}{|c|}{ Openly unemployed } & \multicolumn{2}{|c|}{ LMT vocational } \\
\hline Men & Women & Men & Women \\
\hline $\mathrm{N}=26,020$ & $\mathrm{~N}=23,840$ & $\mathrm{~N}=5,432$ & $\mathrm{~N}=6,995$ \\
\hline
\end{tabular}

AEI compulsory

1 semester

$-5,041$

2 semesters

$-2,498$

3 semesters

$-1,325$

4 semesters

$-7,144$

$10,403^{*}$
$8,309^{* *}$
3,235
659

$5,301^{* * *}$
$12,785^{* * *}$
$22,247^{* * *}$
$9,963^{* * *}$

$-4,177$

6,646

$-1,591$

3,107

AEI upper secondary

1 semester

2 semesters

3 semesters

4 semesters

- 1,039

$5,612^{* * * *}$

$-1,779$

$-1,358$

$-5,863$

$-4,443$

LMT vocational

LMT preparatory

$$
\begin{array}{rr} 
& -1,840^{* *} \\
& -2,946^{* *} \\
R^{2} & .052
\end{array}
$$$$
3,979^{* * *}
$$$$
2,182
$$$$
896
$$$$
7,332^{* * *}
$$$$
9,645^{* * *}
$$$$
7,748^{* * *}
$$$$
5,796^{* *}
$$$$
6,798^{* * *}
$$$$
16,330^{* * *}
$$

$$
.113
$$$$
\begin{gathered}
-- \\
-121^{*} \\
.073
\end{gathered}
$$$$
4,117^{* *}
$$$$
-640
$$

\begin{tabular}{|c|c|c|c|c|}
\hline & $\mathrm{N}=10,503$ & $\mathrm{~N}=6,608$ & $\mathrm{~N}=2,134$ & $\mathrm{~N}=1,596$ \\
\hline \multicolumn{5}{|c|}{ AEI upper secondary } \\
\hline 1 semester & $-7,656^{*}$ & $-1,167$ & $-9,537^{* *}$ & $-2,953$ \\
\hline 2 semesters & $-1,163$ & $-4,008^{* *}$ & $-2,390$ & $-5,188^{* *}$ \\
\hline 3 semesters & $-6,107$ & -837 & $-7,219^{*}$ & $-1,967$ \\
\hline 4 semesters & $-4,546$ & $-1,407$ & $-6,238^{*}$ & $-3,429$ \\
\hline \multirow{3}{*}{$\begin{array}{l}\text { LMT vocational } \\
\text { LMT preparatory }\end{array}$} & 574 & 1,520 & -- & -- \\
\hline & $-4,189^{* *}$ & $-2,121$ & $-5,115^{* *}$ & $-3,129$ \\
\hline & $R^{2} \quad .100$ & .102 & .105 & .140 \\
\hline $\begin{array}{l}{ }^{* * *} \mathrm{si} \\
{ }^{* *} \mathrm{si} \\
{ }^{*} \mathrm{si} \\
\mathrm{sig}\end{array}$ & $\begin{array}{l}t \text { the } 1 \% \text { level. } \\
t \text { the } 5 \% \text { level. } \\
t \text { the } 10 \% \text { leve }\end{array}$ & & & \\
\hline
\end{tabular}

.162

Sample with zero wage earnings in 1996 and in 1997:

Dependent variable; annual wage earnings 1995. 
It should be noted that there is no theoretical guideline as to which year before program is most appropriate to use for the backcasting procedure. We therefore estimated all possible combinations given the years with registered wage earnings at our disposal.

Let us start with the estimates where the group in continued open unemployment is the reference group. With the reduced sample (lower part), the implications from Table 3 of positive effects of the AEI at upper secondary level are not challenged (this also holds true if we use wage earnings in 1994 as dependent variable). In contrast, with the larger sample, there are quite strong indications of a positive bias for both men and women in the AEI at upper secondary level. For the AEI at compulsory level there are no indications of bias. As average wage earnings were much lower in 1996 compared with 2001, the indication of bias makes it awkward to compare the coefficient magnitudes obtained in Table 2 with those of the backcasting. Our interpretation is that the positive effects indicated in Table 2 are put in serious doubt for the female sample. For males, the bias indicated is probably not large enough to off-set the positive effects reported earlier. Using wage earnings in 1995 as dependent variable (not displayed), reduces the bias for females indicated in Table 4 by roughly $35 \%$, while for the male sample with one, three and four semesters, the estimates are insignificant.

Turning to the comparison between the AEI and vocational LMT, recall that there were by and large negative effects indicated in Tables 2 and 3 . The exceptions concerned upper secondary level in the larger sample, males with two semesters and females with three semesters of studies; but the backcasting in Table 4 indicates a positive selection into both these groups. This is seen in the third and the fourth columns. Regarding the AEI at upper secondary level, the backcasting results with the larger sample imply a positive selection bias and that the earlier negative estimates in Table 2 were underestimated. In contrast, with the reduced sample, a negative bias is indicated for males with one, three and four semesters in the AEI as well as for females with two semesters. This implies that the negative estimates in Table 3 were overestimated and that the true average effects should be smaller in magnitude. However, the bias indicated is too small to question the negative signs 
of the coefficients. Again, using the 1994 wage earnings as dependent variable, there is no indication of bias. For the AEI at compulsory level, there are no indications of selection bias.

To set the presented results in a broader context, let us make a rough estimate of a cost-benefit analysis by considering program costs and forgone earnings. We dispense with possible general equilibrium effects on prices and quantities and assume that the official costs for programs reflect the alternative costs for the society. The average cost of a participant in the AEI, weighted by the program length reported in Table A.1, was SEK $44,000 .{ }^{10}$ A measure of forgone earnings is given by the difference in average earnings in 1998 between AEI participants and unemployed persons as reported in Figure 1, about SEK 13,000 a year. Let us assume program effects of, say, SEK 15,000 for men and SEK 10,000 for women, relatively modest figures considering that a measure of productivity should include payroll taxes (about $40 \%$ ). ${ }^{11}$ At a $3 \%$ discount rate, the benefits of the program would surpass the costs in five to seven years.

A similar comparison between the AEI and LMT comes out in favour of LMT. The average program length in the sample was 322 days for AEI and 228 days for LMT. The educational costs of LMT, counted as an average per year, were SEK 85,000 (AMS). Considering shorter program lengths, the extra educational cost of LMT is about SEK 23,000. Shorter program periods mean lower forgone earnings which, in turn, reduce the costs for LMT to only about SEK 18,000 more than for the AEI. Judging from the estimated program effects when the full sample was used, the extra costs of LMT are matched by higher incomes within only a year or two following program completion.

\footnotetext{
${ }^{10}$ Reported program costs per year were SEK 34,000 (Swedish National Agency for Education), implying a program cost per semester of SEK 17,000. Weighting the fractions that stayed in the AEI for 1, 2, 3 and 4 semesters (see Table 1), the sum obtained is 43,537. In calculating the forgone earnings, the length of a semester is assumed to be 18 weeks.

${ }_{11}$ These figures are related to the point estimates presented in this section. The usual caveat applies, point estimates indicate the average effects on earnings and the optimal scale of programs is determined by marginal returns rather than average revenues.
} 


\section{Concluding discussion}

This paper evaluates the effects of comprehensive adult education on annual wage earnings of the long-term unemployed. We use Swedish register data on a large sample of persons in long-term unemployment in 1997. In that year, the government launched the Adult Education Initiative (AEI), a large program of heavily subsidized adult education at compulsory and upper secondary level. The effect of participation in the AEI on subsequent earnings in 2001 is compared with the effect of participation in Labour Market Training (LMT) and the earnings of a group that remained in open unemployment.

When we use the openly unemployed as reference group, the main results imply that two to four semesters of studies in the AEI at upper secondary level had positive effects on annual wage earnings. For the sample of 'full - time' unemployed, we find that the estimated effect can not be explained by selectivity due to time-invariant unobserved heterogeneity. The backcasting procedure suggests, however, that the results for the sample including the part-time employed may have been generated by selection bias, in particular for the female sample.

Generally, our findings indicate no significant effects for those that enrolled in comprehensive education at compulsory level, nor at the upper secondary level when confined to only one semester of education. The latter is in accordance with earlier findings that short comprehensive adult education of the unemployed has very little impact on wage earnings (see Jacobson et al. 2004).

When the reference group is participants in vocational LMT, our findings indicate overall that vocational training of the long-term unemployed brings about a larger increase in gross wage earnings than comprehensive education at the secondary level. In this particular case, this would suggest that the AEI was a better alternative than no program but that it should have been scaled back to the advantage of vocational LMT. It is, however, important to note that data on post-program wage earnings is confined to a period of three years; the long-run effects may differ from the estimated short-run or medium term effects presented here. Moreover, it should be kept in mind that the effects are here 
measured during an economic upturn. Earlier evaluations of LMT have tended to show pro-cyclical effects.

In relation to policy, the results do support the view that subsidized education at the upper secondary level works as a means of improving the labour market situation for the long-term unemployed. This applies to longer programs targeted towards individuals with no income from part-time employment. Rough calculations suggest that the increase in post-program earnings is sufficient to match the alternative costs for both programs and that vocational training seems still to yield a relatively higher surplus. However, these results have to be replicated in other economic environments and a comprehensive analysis of alternative costs should be carried out before strong policy recommendations can be issued. 


\section{Appendix}

Table A.1. Distribution of program duration times.

\begin{tabular}{lll|ll} 
& \multicolumn{2}{c|}{ AEI } & \multicolumn{2}{|c}{ LMT vocational } \\
\cline { 2 - 4 } & $\mathrm{N}=585$ & $\mathrm{~N}=5,189$ & $\mathrm{~N}=5,033$ & \\
& & & -90 days & $18.2 \%$ \\
Last semester & $14.6 \%$ & $14.6 \%$ & $91-180$ days & $24.5 \%$ \\
autumn 1997 & $28.5 \%$ & $39.3 \%$ & $181-270$ days & $22.4 \%$ \\
spring 1998 & $16.6 \%$ & $21.1 \%$ & $271-360$ days & $20.5 \%$ \\
autumn 1998 & $40.1 \%$ & $24.9 \%$ & $>360$ days & $14.4 \%$ \\
spring 1999 & & &
\end{tabular}

Note: Excluded from Table A.1 is LMT preparatory training whose program durations were not reported. Program times were overall shorter for those in vocational LMT. Their mean program time was 228 days with the median 198 days. Forty-six \% had completed their program by January 1,1998 , to be compared with $15 \%$ of the participants in the AEI who left the program after one semester (approximately about the same date).

Compared with other participants in their respective programs, the long-term unemployed in the AEI tended to have shorter program durations whereas the opposite holds for LMT. Of the total population studying with the UBS, $52 \%$ continued for three semesters and $38 \%$ studied four semesters. The mean program duration time in LMT was 146 days. 


\section{Definition of variables:}

AEI; Registered in adult education during the autumn semester of 1997, and receiving the special grant for education and training, UBS.

CHILD(REN); At least one child below the age of 16 living at home.

DISABLED; Classified with a working disability in 1997.

EDUCATIONAL LEVEL; Highest level of education attained by 1997.

FRACTION IN THE AEI; The number enrolled in the AEI in the municipality of residence, divided by the number enrolled in LMT.

FRACTION IN KOMVUX; The number enrolled in komvux in the municipality of residence, divided by the municipal population.

INLAND OF NORRLAND; Municipalities in Norrland without any coastline.

LMT; Registered in LMT on October 15, 1997.

MUNICIPALITY WITH HIGH EDUCATIONAL LEVEL; Equals one for those living in municipalities with a proportion of individuals with completed three-year upper secondary school above the population median, in all 67 of 288 municipalities representing $54.4 \%$ of the population.

REGIONAL EMPLOYMENT LEVEL; The natural logarithm of (number of employed / population aged 20-64) in 90 labour market regions which are defined by Statistics Sweden based on commuting patterns.

REGIONAL POPULATION; The natural logarithm of the total population in 90 labour market regions as defined by Statistics Sweden on the basis of commuting patterns. 
Table A.2; The fractions of various characteristics among openly unemployed as well as participants in the AEI and LMT.

\begin{tabular}{|c|c|c|c|c|c|c|}
\hline \multirow[b]{3}{*}{ High municipal $\%$ of } & \multirow[b]{2}{*}{$\mathrm{N}$} & \multirow[b]{2}{*}{$\begin{array}{c}\% \\
\text { in open } \\
\text { unemp. }\end{array}$} & \multicolumn{2}{|c|}{$\%$ in AEI } & \multicolumn{2}{|c|}{$\%$ in LMT } \\
\hline & & & $\begin{array}{l}\text { upper } \\
\text { sec. } \\
\text { level }\end{array}$ & $\begin{array}{c}\text { compul- } \\
\text { sory } \\
\text { level } \\
\end{array}$ & $\begin{array}{l}\text { Voca- } \\
\text { tional }\end{array}$ & $\begin{array}{c}\text { Prepara- } \\
\text { tory }\end{array}$ \\
\hline & 25,136 & 50.1 & 39.5 & 30.9 & 51.6 & 57.9 \\
\hline Stockholm County & 5,699 & 11.2 & 9.6 & 12.5 & 11.8 & 13.5 \\
\hline Inland of Norrland & 3,516 & 7.0 & 7.4 & 6.3 & 6.3 & 4.4 \\
\hline Zero income 1996 & 23,130 & 46.8 & 32.5 & 35.4 & 44.2 & 53.1 \\
\hline Male & 26,800 & 55.2 & 29.4 & 30.7 & 59.8 & 49.4 \\
\hline - child(ren) at home & 6,316 & 12.5 & 6.5 & 9.9 & 16.4 & 17.3 \\
\hline - married & 9,208 & 18.9 & 8.1 & 10.8 & 20.7 & 23.5 \\
\hline Female & 24,251 & 44.8 & 70.6 & 69.3 & 40.2 & 50.6 \\
\hline - child(ren) at home & 11,187 & 18.9 & 41.7 & 43.0 & 20.3 & 25.7 \\
\hline - married & 10,479 & 19.8 & 28.1 & 29.2 & 15.9 & 23.0 \\
\hline Age $25-29$ & 6,848 & 11.3 & 23.3 & 16.7 & 19.0 & 12.7 \\
\hline Age $30-34$ & 8,522 & 15.2 & 22.3 & 20.5 & 20.6 & 19.4 \\
\hline Age 35-39 & 7,966 & 14.8 & 17.7 & 18.9 & 18.0 & 18.3 \\
\hline Age $40-44$ & 8,118 & 15.9 & 14.6 & 18.9 & 16.2 & 17.7 \\
\hline Age 45-49 & 8,427 & 17.5 & 12.0 & 13.7 & 13.5 & 17.5 \\
\hline Age 50- & 11,170 & 25.2 & 10.1 & 11.3 & 12.6 & 14.4 \\
\hline Elementary school & 5,478 & 12.6 & 3.7 & 8.9 & 4.3 & 8.3 \\
\hline Compulsory school & 10,148 & 20.0 & 20.1 & 30.4 & 16.6 & 19.7 \\
\hline 2-year secondary school. & 22,268 & 41.0 & 62.7 & 49.8 & 44.2 & 37.6 \\
\hline 3-year secondary school. & 6,186 & 11.8 & 8.2 & 6.1 & 16.7 & 17.6 \\
\hline$<3$ years of university & 4,012 & 8.0 & 4.4 & 2.6 & 10.4 & 9.0 \\
\hline$\geq 3$ years of university & 2,959 & 6.2 & .9 & 2.2 & 7.6 & 7.2 \\
\hline Foreign born & 12,059 & 23.5 & 15.0 & 27.3 & 26.6 & 43.3 \\
\hline Born in Sweden & 45,449 & 89.4 & 94.4 & 88.6 & 85.7 & 74.8 \\
\hline Scandinavian & 1,545 & 3.2 & 2.6 & 2.7 & 2.9 & 2.0 \\
\hline European & 2,427 & 4.3 & 1.7 & 4.8 & 7.7 & 14.5 \\
\hline Non-European & 1,630 & 3.2 & 1.4 & 3.9 & 3.7 & 8.6 \\
\hline Eligible for UI & 45,705 & 89.1 & 97.0 & 96.1 & 87.4 & 80.6 \\
\hline Disabled & 12,795 & 27.6 & 14.4 & 22.0 & 16.8 & 26.6 \\
\hline
\end{tabular}


Table A.3. Complete OLS estimation results.

Dependent variable; annual wage earnings 2001.

Reference group: $\quad$ Openly unemployed LMT vocational

$\frac{\text { Men }}{\mathrm{N}=26,800} \frac{\text { Women }}{\mathrm{N}=24,251} \frac{\text { Men }}{\mathrm{N}=5,729} \frac{\text { Women }}{\mathrm{N}=7,143}$

Constant

51,663

40,756

40,477

86,991

AEI

Table 2

Table 2

Table 2

Table 2

Regional population

$109,452^{* * *}$ $48,455^{* * *}$

$69,769^{*}$

$69,420^{* * *}$

Regional employment

$1,372^{* * *}$

$1,472^{* * *}$

$3,991^{* * *}$

$1,966^{* * *}$

Age 25-29

Age 30-34

Age 35-39

Age 40-44

Age 45-49

Compulsory school

$58,366^{* * * *}$

$43,882^{* * *}$

$18,452^{* * *}$

$67,484^{* * *}$

$13,589^{* * *}$

$32,206^{* * *}$

$23,107^{* * *}$

$25,155^{* * *}$

$55,594^{* * *}$

$20,021^{* * *}$

$25,017^{* * *}$

$24,919^{* * *}$

$44,697^{* * * *}$

$22,474^{* * *}$

$16,108^{* * *}$

$35,372^{* * *}$

$25,179^{* * *}$

$-536$

$16,971^{\text {**** }}$

$24,958^{* * *}$

$13,154^{* * *}$

2 year upper sec. school

$7,741^{* * * * *}$

$-1,481$

5,725

$-6,391$

$10,730^{* * *}$

$15,877^{* * * *}$

$20,203^{* * *}$

$4,178^{* *} \quad 10,874$

$-3,177$

$11,646^{* * *} \quad 11,442$

3,984

University $\leq 3$ years

University $>3$ years

Foreign born

$28,526^{* * *}$

$15,207^{* * *}$

$22,456^{* * *}$

$-108$

$27,241^{* * * *}$

$4,283^{* * *}$

$19,425^{* *}$

10,088

$15,430^{* * *}$

$-1,240$

$23,189^{* * *}$

2,395

$49,832^{* * *}$

$23,196^{* * *}$

5,320

$-3,902$

European citizenship

$-1,213$

$-11,225^{* * *}$

$46,246^{* * *}$

$17,108^{*}$

$-29,165^{* * *}$

$-34,280^{* * *}$

$-11,650^{*}$

$-4,005$

Working disability

Eligible for UI

- married

- child(ren)

$12,819^{* * * *}$

$16,769^{* * * *}$

$8,211^{* * * *}$

14,958 ***

7,385

Pre-program wage earnings

- W.E. mean dev. squared

- Zero pre-program W.E.

$-.216$

$9,886^{* * *}$

$.337^{* * *}$

$-.300^{*}$

$-33,430^{* * *}$

$-37,469^{* * *}$

5,157

$7,396^{*}$

$22,385^{* * *}$

$8,019^{* * *}$

69

$9,291^{* * *}$

$-11,794^{* * *}$

$-10,189^{* * *}$

$-.022$

$.339^{* * *}$

$-.371$

$-9,104^{* *}$

$-4,853^{*}$

$R^{2} \quad .131$

.158

.108

.121

Note: $\quad{ }_{* * *}^{*}$ significant at the $1 \%$ level.

** significant at the $5 \%$ level.

* significant at the $10 \%$ level. 
Table A.4; Heckman two-step estimation results of program effects on wage earnings.

Dependent variable; annual wage earnings 2001.

\begin{tabular}{|c|c|c|c|c|}
\hline \multirow[t]{3}{*}{ Reference group: } & \multicolumn{2}{|c|}{ Openly unemployed } & \multicolumn{2}{|c|}{ LMT vocational } \\
\hline & Men & Women & Men & Women \\
\hline & $\mathrm{N}=26,800$ & $\mathrm{~N}=24,251$ & $\mathrm{~N}=5,729$ & $\mathrm{~N}=7,143$ \\
\hline \multicolumn{5}{|l|}{ AEI compulsory } \\
\hline 1 semester & 20,343 & $-56,192^{* * *}$ & 40,069 & 40,399 \\
\hline 2 semesters & 19,168 & $-48,391^{* * *}$ & 38,166 & 49,381 \\
\hline 3 semesters & 7,946 & $-46,692^{* * *}$ & 24,798 & 51,139 \\
\hline 4 semesters & 32,810 & $-43,641^{* * *}$ & 52,486 & 54,003 \\
\hline \multicolumn{5}{|l|}{ AEI upper secondary } \\
\hline 1 semester & $41,757^{*}$ & $-35,794^{* * *}$ & $58,886^{*}$ & $62,337^{*}$ \\
\hline 2 semesters & $57,671^{* *}$ & $-23,461^{* *}$ & $76,400^{* *}$ & $74,861^{* *}$ \\
\hline 3 semesters & $49,214^{*}$ & $-16,723$ & $66,862^{*}$ & $81,606^{* *}$ \\
\hline 4 semesters & 39,814 & $-26,319^{* *}$ & $58,333^{*}$ & $71,615^{*}$ \\
\hline LMT vocational & $35,714^{* * *}$ & $25,371^{* * *}$ & -- & -- \\
\hline LMT preparatory & $20,056^{* * *}$ & $11,276^{* * *}$ & $-18,107^{* * *}$ & $-16,390^{* * *}$ \\
\hline \multirow[t]{2}{*}{ Inverse Mill's Ratio } & $-13,917$ & $22,133^{* * *}$ & $-49,192^{* *}$ & $-51,523^{* *}$ \\
\hline & .131 & .159 & .109 & .121 \\
\hline
\end{tabular}

Note: $\quad{ }^{* * *}$ significant at the $1 \%$ level.

** significant at the $5 \%$ level.

* significant at the $10 \%$ level. 


\section{References}

AMS (1999). 'Uppföljning av kursdeltagare som slutat yrkesinriktad arbetsmarknadsutbildning andra kvartalet 1998', Prora 1999:1, AMS, Stockholm.

Ashenfelter, O. (1978). 'Estimating the effect of training programs on earnings', Review of Economics and Statistics, vol (60), pp 47-57.

Björklund, A., Edin, P.-A., Fredriksson, P. and Kreuger, A. (2003). 'Education, equality and efficiency - An analysis of Swedish school reforms during the 1990s', Report 2004:1, Institute For Labour Market Policy Evaluation, Uppsala.

Egerton, M. and Parry, G. (2001). 'Lifelong debt: rates of return to mature study', Higher Education Quarterly vol (55), pp 4-27.

Ekström, E. (2003). Essays on Inequality and Education. Ph.D. dissertation, Economic Studies 76, Uppsala Universitet.

Greene, W.H. (2003). Econometric Analysis. Prentice Hall, New Jersey.

Grubb, N.W. (2002). 'Learning and earning in the middle, part I: national studies of pre-baccalaureate education', Economics of Education Review vol. (21), pp 299-321.

Harkman, A. (1997). 'Den yrkesinriktade arbetsmarknadsutbildningen 1994 - effekter för individen', Ura 1997:10, AMS, Solna.

Harkman, A., Jansson, F. and Tamás, A. (1996). 'Effects, defects and prospects - an evaluation of labour market training in Sweden', AMS Working Paper 1996:5, Solna.

Heckman, J., LaLonde, R. and Smith, J. (1999). 'The economics and econometrics of active labour market programs', in Ashenfelter, 
O. and Card, D. (eds) Handbook of Labour Economic, Volume 3A, C. 31.

Jacobson, L.S., LaLonde, R.J. och Sullivan, D.G. (2004). 'The returns to community college schooling for displaced workers', Journal of Econometrics, forthcoming.

Jenkins, A., Vignoles, A. Wolf, A. and Galindo-Rueda, F. (2003). 'The determinants and labour market effects of lifelong learning', Applied Economics vol. (35), pp 1711-21.

Larsson, L. (2000). 'Evaluation of Swedish youth labour market programmes', IFAU Working Paper 2000:1, Uppsala.

Leigh, D.E. and Gill, A.M. (1997). 'Labour market returns to community colleges: evidence for returning adults', Journal of Human Resources, Spring 1997, pp 334-53.

Okeke, S. (2001). 'Arbetsmarknadsutbildningen 1999 - effekter för individen', Ura 2001:7, AMS, Stockholm.

Puhani, P. (2000). The Heckman correction for sample selection and its critique. Journal of Economic Surveys vol. (14), pp 53-68.

Regnér, H. (1997). Training at the job and training for a new job: Two Swedish studies. Ph. D. dissertation, SOFI, Stockholm University.

Richardson, C. and van den Bergh, G. (2002). 'Swedish labour market training and the duration of unemployment', Swedish Economic Policy Review vol. (8), pp 175-213.

Sianesi, B. (2001). 'The Swedish active labour market programmes in the 1990s: Overall effectiveness and differential performance', Swedish Economic Policy Review (8), pp 133-69. 
SOU 1998:51. 'Vuxenutbildning och livslångt lärande. Situationen inför och under första året med Kunskapslyftet', Reports of the Government Commission, Ministry of Education and Science, Stockholm.

SOU 1999:39. 'Vuxenutbildning för alla? Andra året med Kunskapslyftet', Reports of the Government Commissions, Ministry of Education and Science, Stockholm.

Steel, J. and Sausman, C. (1997). 'The contribution of graduates to the economy: rates of return', Technical Report 7 of the National Committee of Inquiry into Higher Education, HMSO, London.

Stenberg, A. (2003). An Evaluation of the Adult Education Initiative Relative Labour Market Training. Ph.D. Thesis, Umeå Economic Studies 609.

Vella, F. (1998). 'Estimating models with sample selection bias: A survey', Journal of Human Resources vol (33)(1), pp 127-69.

Öckert, B. (2001). Effects of Higher Education and the Role of Admission Selection. Ph. D. thesis, Swedish Institute for Social Research, Stockholm. 